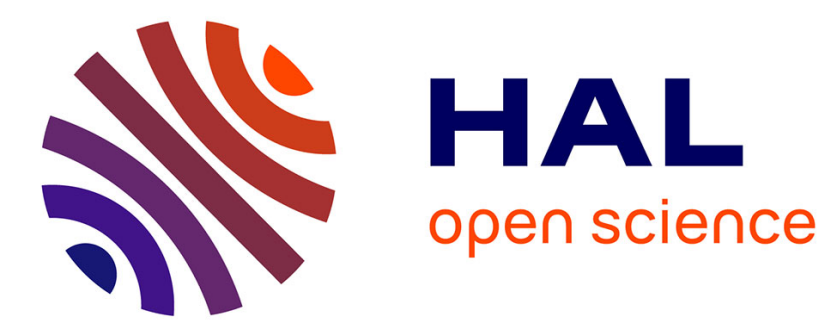

\title{
Development of a biological screening system for the evaluation of highly active, selective 17(-HSD1-inhibitors as potential therapeutic agents
}

Patricia Kruchten, Ruth Werth, Sandrine Marchais-Oberwinkler, Martin Frotscher, Rolf W. Hartmann

\section{To cite this version:}

Patricia Kruchten, Ruth Werth, Sandrine Marchais-Oberwinkler, Martin Frotscher, Rolf W. Hartmann. Development of a biological screening system for the evaluation of highly active, selective 17(-HSD1-inhibitors as potential therapeutic agents. Molecular and Cellular Endocrinology, 2009, 301 (1-2), pp.154. 10.1016/j.mce.2008.09.035 . hal-00532089

\section{HAL Id: hal-00532089 \\ https://hal.science/hal-00532089}

Submitted on 4 Nov 2010

HAL is a multi-disciplinary open access archive for the deposit and dissemination of scientific research documents, whether they are published or not. The documents may come from teaching and research institutions in France or abroad, or from public or private research centers.
L'archive ouverte pluridisciplinaire HAL, est destinée au dépôt et à la diffusion de documents scientifiques de niveau recherche, publiés ou non, émanant des établissements d'enseignement et de recherche français ou étrangers, des laboratoires publics ou privés. 


\section{Accepted Manuscript}

Title: Development of a biological screening system for the evaluation of highly active, selective 17(-HSD1-inhibitors as potential therapeutic agents

Authors: Patricia Kruchten, Ruth Werth, Sandrine Marchais-Oberwinkler, Martin Frotscher, Rolf W. Hartmann

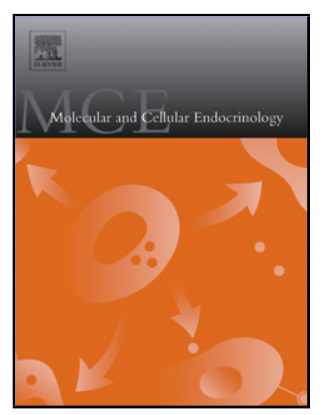

PII: S0303-7207(08)00446-2

DOI: doi:10.1016/j.mce.2008.09.035

Reference: MCE 7005

To appear in: $\quad$ Molecular and Cellular Endocrinology

Received date: $\quad 27-6-2008$

Revised date: 26-9-2008

Accepted date: $\quad$ 27-9-2008

Please cite this article as: Kruchten, P., Werth, R., Marchais-Oberwinkler, S., Frotscher, M., Hartmann, R.W., Development of a biological screening system for the evaluation of highly active, selective 17(-HSD1-inhibitors as potential therapeutic agents, Molecular and Cellular Endocrinology (2008), doi:10.1016/j.mce.2008.09.035

This is a PDF file of an unedited manuscript that has been accepted for publication. As a service to our customers we are providing this early version of the manuscript. The manuscript will undergo copyediting, typesetting, and review of the resulting proof before it is published in its final form. Please note that during the production process errors may be discovered which could affect the content, and all legal disclaimers that apply to the journal pertain. 


\section{Development of a biological screening system for the evaluation of highly active and selective 17 $\beta$-HSD1-inhibitors as potential therapeutic agents}

Patricia Kruchten, Ruth Werth, Sandrine Marchais-Oberwinkler, Martin Frotscher and Rolf W. Hartmann ${ }^{*}$

8.2 Pharmaceutical and Medicinal Chemistry, Saarland University, PO Box 1511 50, D-66041 Saarbrücken, Germany

* Author to whom correspondence should be addressed.

Tel: +4968130270300

Fax: +4968130270308

e-mail: rwh@mx.uni-saarland.de

http://www.pharmmedchem.de 
Abbreviations: $17 \beta$-HSD1, 17 $\beta$-hydroxysteroid dehydrogenase type 1; 17 $\beta$-HSD2, 17 $\beta$ hydroxysteroid dehydrogenase type 2; E1, estrone; E2, 17 $\beta$-estradiol; ER, estrogen receptor; MTT, 3-(4,5-dimethylthiazol-2-yl)-2,5-diphenyl-tetrazolium bromide; ; PAMPA, parallel artificial membrane permeability assay; SAR, structure-activity relationship; TEER, transepithelial electrical resistance 
Keywords: $17 \beta$-HSD1-inhibitors, drug development, estrogen dependent disease, metabolic stability, screening system, selectivity (17 $\beta-\mathrm{HSD} 2$, hepatic CYPs, estrogen receptor).

\begin{abstract}
17 $\beta$-Hydroxysteroid dehydrogenase type 1 (17 $\beta$-HSD1) catalyses the intracellular conversion of oestrone (E1) to oestradiol (E2). E2 is known to be involved in the development and progression of breast cancer and endometriosis. Since 17 $\beta$-HSD1 is overexpressed in these oestrogen-dependent diseases, inhibition of this enzyme may be a more target-directed therapeutical approach compared to established medical treatments. For the identification of highly active and selective 17 $\beta$-HSD1-inhibitors that are suitable for application as potential therapeutics, there is a need for an appropriate, efficient and reliable screening system. Here, we report the development and application of our screening system using our in house library of potential $17 \beta$-HSD1-inhibitors. Four potent and selective compounds with a good first pharmacokinetic profile were identified.
\end{abstract}




\section{Introduction}

$17 \beta$-HSD1 catalyses the NADPH dependent reduction of the weak oestrogen E1 to E2 (final step of oestrogen biosynthesis). E2 is the principal and most potent oestrogen in humans. In addition to non-genomic effects, it performs crucial functions in the endocrine system by binding to the oestrogen receptors (ERs). However, it has also been shown to stimulate the proliferation of diseases such as endometriosis (Zeitoun et al., 1998) and breast cancer (Thomas, 1984; Vihko et al., 2003). 17ß-HSD1 is overexpressed in endometrial tissue (Šmuc et al., 2007) and in many breast tumours. This leads to a high intracellular concentration of E2 which activates cell proliferation (Miyoshi et al., 2001). Inhibition of this enzyme is therefore an attractive novel concept for the treatment of oestrogen-dependent diseases. Compared to established endocrine therapies that systemically reduce E2 action, fewer side effects are expected.

To be suitable as potential therapeutics $17 \beta$-HSD1-inhibitors must meet several requirements. High $17 \beta$-HSD1 inhibitory activity and low inhibition of its physiological counterpart $17 \beta$ HSD2 (Wu et al., 1993) are essential. Besides, the inhibitors must not activate the ERs $\alpha$ and $\beta$ to avoid stimulation of tumour growth. Moreover, good intestinal absorption, sufficient metabolic stability and low interaction with hepatic CYP-enzymes are very important. Consequently, it is necessary to have a biological screening system on hand for the evaluation of active compounds. Here, we describe our biological test system that enabled us to identify two series of highly active non-steroidal $17 \beta$-HSD1-inhibitors with good selectivities towards 17 $\beta$-HSD2 and both ER subtypes (Bey et al., 2008; Frotscher et al., 2008; MarchaisOberwinkler et al., 2008).

\section{Materials and methods}

\subsection{Cell-free competitive inhibition assay on human 17 $\beta$-HSD1}

The assay was performed similar as described by Sam et al. (Sam et al., 1998). Briefly, human enzyme was partially purified from placental tissue and incubated with $\left[2,4,6,7-{ }^{3} \mathrm{H}\right]-\mathrm{E} 1(500$ $\mathrm{nM}$ ) for $10 \mathrm{~min}$ at $37^{\circ} \mathrm{C}$ in the presence of $\mathrm{NADH}$. After ether extraction, substrate and product were separated by HPLC and detected with a radioflow detector (Berthold Technologies, Bad Wildbad) (Frotscher et al., 2008).

\subsection{Cell-free competitive inhibition assay on human 17ß-HSD2}

Human enzyme is partially purified from placental tissue and incubated with $\left[2,4,6,7-{ }^{3} \mathrm{H}\right]-\mathrm{E} 2(500 \mathrm{nM})$ for $20 \mathrm{~min}$ at $37{ }^{\circ} \mathrm{C}$ in the presence of $\mathrm{NAD}^{+}$. After ether extraction, substrate and product were separated by HPLC and detected with a radioflow detector (Frotscher et al., 2008).

\subsection{Competitive ER binding assay}

ER-binding affinity was determined similarly to a previously described method (Zimmermann et al., 2005). ER $\alpha$ or ER $\beta$ was incubated with $\left[2,4,6,7-{ }^{3} \mathrm{H}\right]-\mathrm{E} 2$ and inhibitor for $1 \mathrm{~h}$ at room temperature. Receptor-bound and free E2 were separated by means of hydroxyapatite. The amount of bound radioactivity was measured in a liquid scintillation counter. Non-specific binding was determined with diethylstilbestrol (Bey et al., 2008).

\subsection{Cytotoxicity assay}

For evaluation of cytotoxicity, conversion of MTT was determined as described by Denizot and Lang with minor modifications (Denizot and Lang, 1986). T47-D cells were incubated with the inhibitor for $3 \mathrm{~h}$ at $37{ }^{\circ} \mathrm{C}$ in a $5 \% \mathrm{CO}_{2}$ humidified atmosphere. After an MTTincubation of $3 \mathrm{~h}$ the cleavage of MTT to a blue formazane by mitochondrial succinatedehydrogenase was quantified spectrophotometrically at $590 \mathrm{~nm}$. 


\subsection{Cellular activity}

T47-D cells were pre-incubated with the inhibitor for $30 \mathrm{~min}$. After $30 \mathrm{~min}$ incubation with $\left[2,4,6,7-{ }^{3} \mathrm{H}\right]-\mathrm{E} 1$ at $37{ }^{\circ} \mathrm{C}$ in a $5 \% \mathrm{CO}_{2}$ humidified atmosphere the supernatant was extracted with ether. Probe analysis was performed according to the cell-free inhibition assays.

\subsection{Oestrogenicity assay}

T47-D cells were grown in phenolred-free medium supplemented with stripped fetal calf serum. T47-D cells were incubated with the compounds for 10 days at $37{ }^{\circ} \mathrm{C}$ in a $5 \% \mathrm{CO}_{2}$ humidified atmosphere. The medium containing the respective inhibitor was exchanged every 2 to 3 days. E2 was used as positive, ethanol as a negative control. Determination of cell number was performed by MTT-conversion as described for the cytotoxicity assay.

\subsection{CaCo2-permeability assay}

CaCo-2 cell culture and transport experiments are performed as described by Yee (Yee, 1997) with small modifications. Four reference compounds (atenolol, testosterone, ketoprofene, erythromycin) were used in each assay for validation. Samples were taken from the acceptor side after 0, 60, 120 and $180 \mathrm{~min}$, and from the donor side after 0 and $180 \mathrm{~min}$. The integrity of the monolayers is checked by measuring the transepithelial electrical resistance (TEER) before the transport experiments and by measuring lucifer yellow permeability after each assay. All samples of the CaCo-2 transport experiments are analysed by HPLC-MS/MS.

\subsection{Metabolic stability assay}

The assay is performed with liver microsomes from rats (Sprague Dawley, male pool; BD Gentest, USA). The incubation consists of a microsomal suspension of $0.33 \mathrm{mg} / \mathrm{ml}$ protein in phosphate buffer $\mathrm{NADP}^{+}$-regenerating system $\left(\mathrm{NADP}^{+}\right.$, glucose-6-phosphate, glucose-6phosphate dehydrogenase, $\mathrm{MgCl}_{2}$ ). The reaction is initiated by the addition of test compound (final concentration $1 \mu \mathrm{M}$ ) to the pre-incubated microsomes/buffer mix at $37^{\circ} \mathrm{C}$. The samples are removed from the incubations after $0,15,30$, and $60 \mathrm{~min}$, and processed for acetonitrile precipitation. Analysis is performed by LC-MS/MS.

\subsection{Inhibition of hepatic CYP-enzymes}

The commercially available P450 inhibition kits from BD Gentest (Heidelberg, Germany) are used according to the manufactorer's instructions. Compounds are tested for inhibition of the following enzymes: CYP1A2, 2B6, 2C9, 2C19, 2D6 and 3A4. Inhibitory potencies are determined as $\mathrm{IC}_{50}$-values.

\subsection{In vivo pharmacokinetics}

Male Wistar rats weighing 300-330 g (Janvier, France) are housed in a temperature-controlled room $\left(20-22^{\circ} \mathrm{C}\right)$ and maintained in a $12 \mathrm{~h}$ light/ $12 \mathrm{~h}$ dark cycle. Food and water are available ad libitum. Compounds are applied orally in a cassette dosing to four rats by using a feeding needle. The compounds are dissolved in a mixture labrasol/water $(1: 1)$ and given at a volume of $5 \mathrm{ml} / \mathrm{kg}$. Blood samples $(0.2 \mathrm{ml})$ are taken at $0,1,2,3,4,6,8,10$ and $24 \mathrm{~h}$ postdose and analysed by HPLC-MS/MS.

\section{Results}

3.1 Requirements of 17 $\beta$-HSD1-inhibitors as potential therapeutic agents

For the design of a screening system that can assess relevant aspects of $17 \beta$-HSD1-inhibitors as potential therapeutics it is necessary to establish the corresponding single tests for the evaluation of different properties and combine them into an efficient screening system. Important properties of the inhibitors as well as appropriate tests are given in Table 1. 


\section{Table 1}

3.2 Description of the developed screening system

The first and principle feature is a high inhibitory activity towards the target enzyme 17 $\beta$ HSD1. It can be evaluated quickly by a competitive inhibition assay using the partially purified human enzyme. With this test it is possible to deduce reliable structure-activity relationships (Salhab et al.). Besides, it is also important that inhibitors are active intracellularly. This property can be investigated by a cellular assay. Moreover, this assay provides first insights into cell permeability, intracellular metabolism and protein adsorption. To avoid side effects the physiological counterpart of the target enzyme, 17 $\beta$-HSD2, which catalyses the reverse reaction, should not be blocked (Fig. 1).

\section{Figure 1}

Therefore, a cell free competitive inhibition assay using the human 17 $\beta$-HSD2 must be applied at an early stage to gain additional SAR regarding selectivity. For a comparison of the inhibitors, $\mathrm{IC}_{50}$-values are determined in both cell-free assays and selectivity factors are calculated. A second aspect of selectivity concerns the ERs. Neither an agonistic nor antagonistic effect is acceptable, as side effects could also be evoked via ER-antagonism. For this reason, binding affinity is evaluated for each subtype of human ER ( $\alpha$ and $\beta$ ) in a competitive binding assay. Going beyond the step of ligand binding in a second functional test, the proliferation stimulating properties of the inhibitors are evaluated in a cellular system with the oestrogen-dependent breast cancer cell line T47-D. For the evaluation of toxic effects, a further cellular assay has been established. Acute cytotoxicity is assessed by determining the number of living cells after a short incubation time using the MTT-test. Chronic cytotoxic effects may also be seen in the oestrogenicity assay, in which the cells are incubated with inhibitor for ten days.

In addition to these pharmacodynamic considerations pharmacokinetic aspects play also an important role in preclinical drug design. A prerequisite for the application of a compound as therapeutic is good absorption in the gastrointestinal tract. A first evidence on cell permeability is given by the cellular inhibition test mentioned before. For the determination of intestinal absorption a CaCo2-permeability assay is performed. In contrast to artificial membrane models such as PAMPA (parallel artificial membrane permeability assay) this colon carcinoma derived cell line allows for the observation of relevant metabolic steps and active transport processes in the gastrointestinal tract. To ensure a high throughput a cassette dosing procedure has been developed. Interference with liver metabolism is of special interest in drug development. On the one hand the compounds must display sufficient metabolic stability in order to reach the target. Therefore, metabolic stability is assessed by the determination of the half life time in rat liver microsomes. On the other hand the compounds should not inhibit the degradation of other endogenous or exogenous substances. To evaluate this effect inhibition of the six most important hepatic CYP-enzymes is determined in a cellfree assay. The final step in the evaluation process is an in vivo test in rats that is performed to assess the pharmacokintetic profile of the inhibitors.

\section{Figure 2}

For the development of a powerful screening system that provides a maximum of information it is necessary to apply the single evaluation steps in a reasonable and efficient order (Fig. 2). In every single step inhibitors undergo selection. By application of this screening sequence hit structures can be identified, the development to lead structures is supported, input in the optimisation of these lead structures is provided, and candidate substances for further evaluation can be proposed. For the fast determination of SAR three cell-free activity and selectivity assays are performed. Before applying cellular assays, cytotoxic effects are determined to make sure that the measured inhibitions are not artifactual. Subsequently, intracellular inhibition, as well as oestrogenic effects, is determined. Intestinal absorption is only determined for compounds which are intracellularly active and non oestrogenic. After 
that the interplay of inhibitors and hepatic enzymes is evaluated in two steps followed by pharmacokinetic studies in rats. For the determination of in vivo activity several models are described (Day et al., 2008; Einspanier et al., 2006; Grümmer et al., 2001; Husen et al., 2006; Laschke et al., 2005). Presently, the most appropriate for our screening procedure is being elaborated.

Figure 3

3.3 Application of the established screening system

For the evaluation of the effectiveness of the developed screening system 214 non-steroidal compounds of different structural classes were designed, synthesised and tested (Fig. 3). Eighty-two compounds were highly active $17 \beta$-HSD1 inhibitors with $\mathrm{IC}_{50}$-values below 1 $\mu \mathrm{M}$, and 23 of these were also selective against 17 $\beta$-HSD2. The latter compounds were evaluated in the ER-affinity tests. Sixteen turned out to have a very low affinity to both ER subtypes and no cytotoxic effects on T47-D cells. Five of these showed a good intracellular activity. After performing the oestrogenicity test, four compounds turned out to be candidates for extended pharmacokinetic evaluation.

\section{Discussion and Conclusion}

As mentioned above, non-steroidal compounds are of major interest. Fewer side effects are expected from these compounds, since the non-steroidal scaffold should show less affinity to other steroid-binding proteins. Nevertheless, the affinity of our compounds for the ERs is of particular interest, because ER $\alpha$ agonismon would leads to further disease progression and thus impairs the therapeutic benefit. An agonistic effect on ER $\beta$ might have a benefit in the treatment of oestrogen-dependent diseases due to the putative antiproliferative effect of this receptor (Matthews and Gustafsson, 2003; Ström et al., 2004). However, this may lead to ER $\beta$-derived side effects. Conversely, ER $\alpha$ antagonists decrease proliferation, but they also show typical anti-oestrogenic side effects. Therefore, an ER $\alpha$ antagonism is also not tolerable for this approach. Since a deficiency of ER $\beta$ might lead to uterine hyperproliferation, ER $\beta$ antagonism is also undesirable (Weihua et al., 2000). For these reasons, we performed two ER-binding assays that enabled us to deduce SAR for the development of compounds with no or low affinity to the ERs.

For a closer investigation of the compounds there is a need for a cellular model that fulfills the following requirements. First, the cells should be of mammalian origin and be related to one of the oestrogen-dependent diseases. Secondly, they must express 17 $\beta$-HSD1 and 17ß-HSD2. Stronger expression of the former is desirable, as this is the case in the diseased tissue. Moreover, the cells should express ER $\alpha$ and ER $\beta$, which leads to oestrogen dependent proliferation. For this reason, we consider that T47-D cells are very appropriate for the in vitro studies.

After investigating the important aspects as mentioned above, the compounds must be evaluated in disease models. Using different animal models, 17 $\beta$-HSD1 has been validated as an appropriate target for treating breast cancer and endometriosis (Einspanier et al., 2006; Grümmer et al., 2001). For the investigation of the in vivo activity of our compounds we are presently examining their PK-profile and their inhibitory potency on E2-formation in the corresponding species.

In the present study we have established several single tests and combined them into a powerful screening system. In this test sequence, relevant properties of potential therapeutics were investigated at an early stage of inhibitor development. A number of non-steroidal compounds were evaluated. Using the single assays SAR were deduced and applied for the optimisation of the synthesised compounds. As a result two series of novel 17 $\beta$-HSD1inhibitors with promising features were discovered. The most interesting compounds were highly active and selective inhibitors of $17 \beta$-HSD1 and showed goodpharmacokinetic properties. They are candidates for a further preclinical development. 


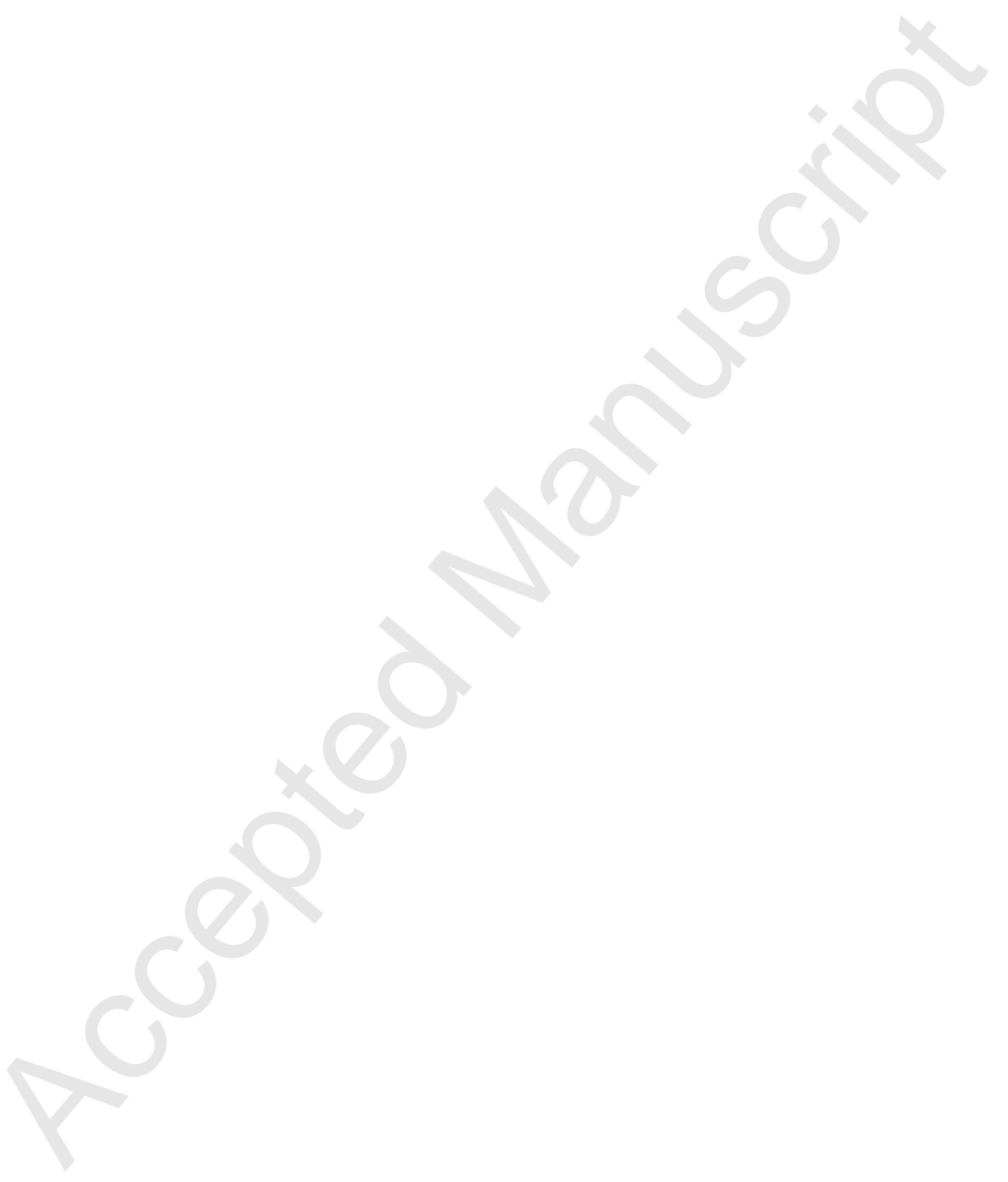

$-8-$

Page 8 of 15 


\section{Acknowledgement}

We are grateful to the Deutsche Forschungsgemeinschaft for financial support (HA1313/8-1) of this work. Patricia Kruchten is grateful for a scholarship from the European Postgraduate School (DFG) GRK532. We thank Pharmacelsus CRO for their good cooperation in terms of pharmacokinetic studies and Elexopharm $\mathrm{GmbH}$ for their collaboration. We thank Dr. Erika Ziegler and Emmanuel Bey for the preparation of the compounds. 


\section{References}

Bey, E., Marchais-Oberwinkler, S., Kruchten, P., Frotscher, M., Werth, R., Oster, A., Algül, O., Neugebauer, A., Hartmann, R.W., 2008. Design, synthesis and biological evaluation of bis(hydroxyphenyl) azoles as potent and selective non-steroidal inhibitors of 17betahydroxysteroid dehydrogenase type 1 (17beta-HSD1) for the treatment of estrogen-dependent diseases. Bioorg. Med. Chem. 16, 6423-6435.

Day, J.M., Foster, P.A., Tutill, H.J., Parsons, M.F., Newman, S.P., Chander, S.K., Allan, G.M., Lawrence, H.R., Vicker, N., Potter, B.V., Reed, M.J., Purohit, A., 2008. 17betahydroxysteroid dehydrogenase type 1 , and not type 12 , is a target for endocrine therapy of hormone-dependent breast cancer. Int. J. Cancer 122, 1931-1940.

Denizot, F., Lang, R., 1986. Rapid colorimetric assay for cell growth and survival. Modifications to the tetrazolium dye procedure giving improved sensitivity and reliability. J. Immunol. Methods 89, 271-277.

Einspanier, A., Lieder, K., Brüns, A., Husen, B., Thole, H., Simon, C., 2006. Induction of endometriosis in the marmoset monkey (Callithrix jacchus). Mol. Hum. Reprod. 12, 291-299.

Frotscher, M., Ziegler, E., Marchais-Oberwinkler, S., Kruchten, P., Neugebauer, A., Fetzer, L., Scherer, C., Müller-Vieira, U., Messinger, J., Thole, H., Hartmann, R.W., 2008. Design, synthesis, and biological evaluation of (hydroxyphenyl)naphthalene and -quinoline derivatives: potent and selective nonsteroidal inhibitors of 17beta-hydroxysteroid dehydrogenase type 1 (17beta-HSD1) for the treatment of estrogen-dependent diseases. J. Med. Chem. 51, 2158-2169.

Grümmer, R., Schwarzer, F., Bainczyk, K., Hess-Stumpp, H., Regidor, P.A., Schindler, A.E., Winterhager, E., 2001. Peritoneal endometriosis: validation of an in-vivo model. Hum. Reprod. 16, 1736-1743.

Husen, B., Huhtinen, K., Saloniemi, T., Messinger, J., Thole, H.H., Poutanen, M., 2006. Human hydroxysteroid (17-beta) dehydrogenase 1 expression enhances estrogen sensitivity of MCF-7 breast cancer cell xenografts. Endocrinology 147, 5333-5339.

Laschke, M.W., Elitzsch, A., Vollmar, B., Menger, M.D., 2005. In vivo analysis of angiogenesis in endometriosis-like lesions by intravital fluorescence microscopy. Fertil. Steril. 84 Suppl 2, 1199-1209.

Marchais-Oberwinkler, S., Kruchten, P., Frotscher, M., Ziegler, E., Neugebauer, A., Bhoga, U., Bey, E., Müller-Vieira, U., Messinger, J., Thole, H., Hartmann, R.W., 2008. Substituted 6phenyl-2-naphthols. Potent and selective non-steroidal inhibitors of $17 \beta$-hydroxysteroid dehydrogenase type 1 (17ß-HSD1): design, synthesis, biological evaluation and pharmacokinetics. J. Med. Chem. 51, 4685-4698.

Matthews, J., Gustafsson, J.Á., 2003. Estrogen signaling: a subtle balance between ER alpha and ER beta. Mol. Interv. 3, 281-292.

Miyoshi, Y., Ando, A., Shiba, E., Taguchi, T., Tamaki, Y., Noguchi, S., 2001. Involvement of up-regulation of 17beta-hydroxysteroid dehydrogenase type 1 in maintenance of intratumoral high estradiol levels in postmenopausal breast cancers. Int. J. Cancer 94, 685-689. 
Salhab, M., Reed, M.J., Al Sarakbi, W., Jiang, W.G., Mokbel, K., 2006. The role of aromatase and 17-beta-hydroxysteroid dehydrogenase type 1 mRNA expression in predicting the clinical outcome of human breast cancer. Breast Cancer Res Treat 99, 155-162.

Sam, K.M., Boivin, R.P., Tremblay, M.R., Auger, S., Poirier, D., 1998. C16 and C17 derivatives of estradiol as inhibitors of 17 beta-hydroxysteroid dehydrogenase type 1: chemical synthesis and structure-activity relationships. Drug. Des. Discov. 15, 157-180.

Šmuc, T., Pucelj, M.R., Šinkovec, J., Husen, B., Thole, H., Lanišnik Rižner, T., 2007. Expression analysis of the genes involved in estradiol and progesterone action in human ovarian endometriosis. Gynecol. Endocrinol. 23, 105-111.

Ström, A., Hartman, J., Foster, J.S., Kietz, S., Wimalasena, J., Gustafsson, J.Á., 2004. Estrogen receptor beta inhibits 17beta-estradiol-stimulated proliferation of the breast cancer cell line T47D. Proc. Natl. Acad. Sci. U S A 101, 1566-1571.

Thomas, D.B., 1984. Do hormones cause breast cancer? Cancer 53, 595-604.

Vihko, P., Härkönen, P., Oduwole, O., Törn, S., Kurkela, R., Porvari, K., Pulkka, A., Isomaa, V., 2003. 17 beta-hydroxysteroid dehydrogenases and cancers. J. Steroid Biochem. Mol. Biol. $83,119-122$.

Weihua, Z., Saji, S., Makinen, S., Cheng, G., Jensen, E.V., Warner, M., Gustafsson, J.Á., 2000. Estrogen receptor (ER) beta, a modulator of ER alpha in the uterus. Proc. Natl. Acad. Sci. U S A 97, 5936-5941.

Wu, L., Einstein, M., Geissler, W.M., Chan, H.K., Elliston, K.O., Andersson, S., 1993. Expression cloning and characterization of human 17 beta-hydroxysteroid dehydrogenase type 2, a microsomal enzyme possessing 20 alpha-hydroxysteroid dehydrogenase activity. J. Biol. Chem. 268, 12964-12969.

Yee, S., 1997. In vitro permeability across Caco-2 cells (colonic) can predict in vivo (small intestinal) absorption in man--fact or myth. Pharm. Res. 14, 763-766.

Zeitoun, K., Takayama, K., Sasano, H., Suzuki, T., Moghrabi, N., Andersson, S., Johns, A., Meng, L., Putman, M., Carr, B., Bulun, S.E., 1998. Deficient 17beta-hydroxysteroid dehydrogenase type 2 expression in endometriosis: failure to metabolize 17 beta-estradiol. J. Clin. Endocrinol. Metab. 83, 4474-4480.

Zimmermann, J., Liebl, R., von Angerer, E., 2005. 2,5-Diphenylfuran-based pure antiestrogens with selectivity for the estrogen receptor alpha. J. Steroid Biochem. Mol. Biol. 94, 57-66.

Table 1 Requirements for inhibitors and corresponding tests 


\begin{tabular}{|c|c|c|}
\hline & $\begin{array}{l}\text { Necessary properties for } \\
17 \beta \text {-HSD1-inhibitors as potential } \\
\text { therapeutic agents }\end{array}$ & $\begin{array}{l}\text { Relevant assays for the evaluation of the } \\
\text { inhibitors }\end{array}$ \\
\hline 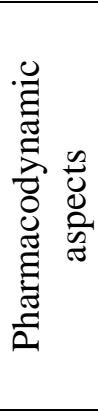 & $\begin{array}{l}\text { High inhibitory activity at the } \\
\text { target enzyme } \\
\text { Selectivity towards } 17 \beta-\text { HSD2 } \\
\text { No (anti-)oestrogenic effects } \\
\text { No acute or chronic toxicity }\end{array}$ & $\begin{array}{l}\text { - Cell-free } 17 \beta-H S D 1 \text { inhibition assay } \\
\text { - Cellular } 17 \beta-H S D 1 \text { inhibition assay } \\
\text { - Cell-free } 17 \beta-H S D 2 \text { inhibition assay } \\
\text { - } \text { Competitive ER } \alpha \text { and ER } \beta \text { binding } \\
\text { - } \text { assay } \\
\text { - } \quad \text { T47-D proliferation test } \\
\\
\text { - } \text { (acute) } \\
\text { T47-D proliferation test (chronic) }\end{array}$ \\
\hline 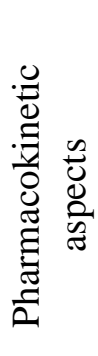 & $\begin{array}{l}\text { Good cellular absorption } \\
\text { Low interference with liver } \\
\text { metabolism } \\
\text { Pharmacokinetic properties }\end{array}$ & $\begin{array}{l}\text { - Cellular inhibition assay } \\
\text { - CaCo2-permeability test } \\
\text { - Rat liver microsome stability assay } \\
\text { - CYP-inhibition assays } \\
\text { - In vivo test in rats }\end{array}$ \\
\hline
\end{tabular}


Figure 1:

Interconversion of estrone (E1) and 17 $\beta$-estradiol (E2) by 17 $\beta$-HSDs<smiles>C[C@]12CCC3c4ccc(O)cc4CCC3C1CCC2=O</smiles>

E1

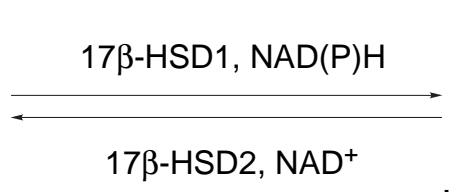

$\mathrm{HO}$

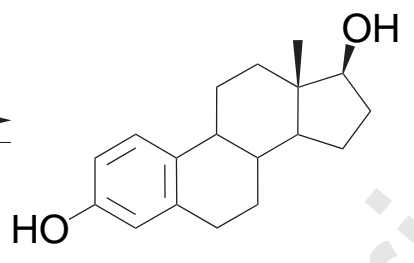

E2 
Figure 2: Combination of single assays to a powerful screening system

\begin{tabular}{|c|c|}
\hline $\begin{array}{l}\text { Inhibitor } \\
\text { identification }\end{array}$ & $\begin{array}{l}\text { Competitive inhibition assay } \\
\text { (human } 17 \beta \text { HSD1 from placental tissue) }\end{array}$ \\
\hline \multirow{2}{*}{ Selectivity } & $\begin{array}{l}\text { Competitive inhibition assay } \\
\text { (human } 17 \beta \text { HSD2 from placental tissue) }\end{array}$ \\
\hline & $\begin{array}{c}\text { Competitive binding assay } \\
\text { (both subtypes of human estrogen receptor; } \\
\text { ER } \alpha \text { and ER } \beta \text { ) }\end{array}$ \\
\hline Toxicity in vitro & $\begin{array}{c}\text { Cytotoxicity assay } \\
\text { (mammalian cells; T47-D) }\end{array}$ \\
\hline Intracellular activity & $\begin{array}{l}\text { Cellular activity assay } \\
\text { (mammalian cells; T47-D) }\end{array}$ \\
\hline Estrogenicity & $\begin{array}{c}\text { Proliferation assay } \\
\text { (MTT; mammalian cells; T47-D) }\end{array}$ \\
\hline $\begin{array}{l}\text { Intestinal } \\
\text { absorption }\end{array}$ & CaCo2-permeability assay \\
\hline Metabolic stability & $\begin{array}{l}\text { Metabolic stability assay } \\
\text { (rat liver microsomes) }\end{array}$ \\
\hline $\begin{array}{l}\text { Risk of drug-drug- } \\
\text { interactions } \\
\text { in vitro }\end{array}$ & $\begin{array}{l}\text { Inhibition of hepatic enzymes } \\
\text { (CYP1A2, CYP3A4, CYP2B6, CYP2C9, } \\
\text { CYP2C19, CYP2D6) }\end{array}$ \\
\hline $\begin{array}{l}\text { Pharmacokinetic } \\
\text { properties in vivo }\end{array}$ & $\begin{array}{l}\text { Pharmacokinetic studies } \\
\text { in rat model }\end{array}$ \\
\hline & Activity in vivo \\
\hline
\end{tabular}


Figure 3: Efficiency of the screening system

Compound collection consisting of 214

potential 17ß-HSD1-inhibitors

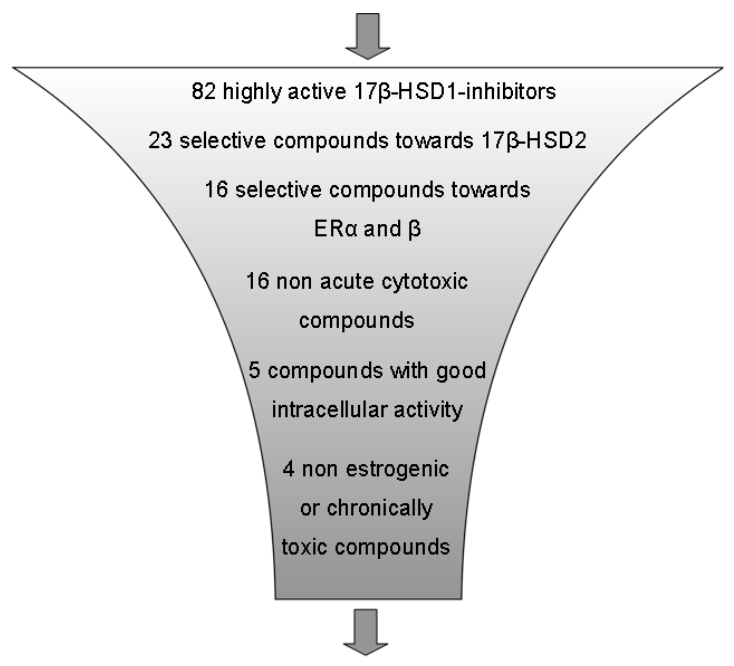

Selected compounds for extended

evaluation 